\title{
Characterization of Streptomycetes Causing Potato Common Scab in Korea
}

\author{
Duck Hwan Park, Division of Biological Environment, College of Agriculture and Life Sciences, Gangwon National \\ University, Chunchon 200-701, Korea; Yong Man Yu, Central Research Institure, Kyung Nong Corporation, 226 \\ Guhwang-dong, Gyungju 780-110, Korea; Jeom Soon Kim, Alpine Agricultural Experiment Station, Pyeongchang, \\ Gangwon 232-950, Korea; and Jun Mo Cho, Jang Hyun Hur, and Chun Keun Lim, Division of Biological Envi- \\ ronment, College of Agriculture and Life Sciences, Gangwon National University, Chunchon 200-701, Korea
}

\begin{abstract}
Park, D. H., Yu, Y. M., Kim, J. S., Cho, J. M., Hur, J. H., and Lim, C. K. 2003. Characterization of streptomycetes causing potato common scab in Korea. Plant Dis. 87:1290-1296.

Six representative Korean strains of streptomycetes (S33, S27, S71, S63, S77, and S78) that were pathogenic to potato were characterized based on phenotypic properties, analysis of $16 \mathrm{~S}$ rRNA genes, production of thaxtomin A, and presence of necl and ORFtnp gene homologs. Strains S33 and S27 had typical characteristics of Streptomyces scabies and S. turgidiscabies, respectively, producing thaxtomin A and hybridizing to genes of necl and ORFtnp. Strain S71 produced thaxtomin A and had phenotypic and phylogenetic properties similar to those of $S$. acidiscabies, except having a greater minimum growth $\mathrm{pH}$ (4.5), production of a melanoid pigment on tyrosine agar, and failure to hybridize with necl and ORFtnp gene probes. In contrast, strains S63, S77, and S78 were phenotypically different from described scab pathogens. Spore colors of strains S63 and S77 were yellow-white or pale orange, respectively, with rectiflexuous chains. Strain S78 had thin and compact spores unlike typical S. acidiscabies (ATCC 49003). Phylogenetic analysis of strains S63, S77, and S78 based on 16S rRNA gene sequences showed low homology to that of described scab pathogens (less than 97.3, 96.0, and 96.3\%, respectively). Strain S78 produced thaxtomin A, but did not have homologous sequences to necl and ORFtnp genes. Production of thaxtomin A and gene homologs of necl and ORFtnp were not detected in strains S63 and S77. All three strains grow at low pH, with minimal growth at $\mathrm{pH}$ 3.5 (S77 and S78) or 4.5 (S63). Streptomyces strains S63, S77, and S78 are novel pathogenic streptomycetes adapted to acidic soil conditions in Korea.
\end{abstract}

Additional keywords: horizontal transfer, phytotoxin, potato scab

Potato common scab occurs in essentially all potato growing areas of the world (5,12-16,20,22,24,32). Although scab does not affect total yields, significant economic losses result from reduced marketability because of tuber defects. Several pathogenic Streptomyces species have been described to date. Streptomyces scabies was first described by Thaxter (1892) and reproposed by Lambert and Loria (17) as the predominant species causing common scab of potatoes. A distinct acid-tolerant species, $S$. acidiscabies, induces symptoms similar to $S$. scabies (18). S. turgidiscabies was described from Japan (26). This species is distinct from both $S$. scabies and $S$. acidiscabies based on DNA-DNA homology, ribosomal DNA sequences, and morphological characteristics (32). S. europaeiscabiei and S. stelliscabiei were reported to cause common scab of potato, while $S$.

Corresponding author: Chun Keun Lim

E-mail: chunkeun@kangwon.ac.kr

Accepted for publication 30 May 2003.

Publication no. D-2003-0828-01R

(C) 2003 The American Phytopathological Society reticuliscabiei was identified as a cause of netted scab in France (2).

In Korea, potato has been cultivated for more than 100 years, but common scab disease was not recognized until the mid1980s. Since this period, following an increase in cultivation, common scab has been a major limiting factor in potato production. S. scabies, S. turgidiscabies, and $S$. acidiscabies have been identified as common scab pathogens in Korea (13-15). However, Streptomyces spp. other than these three species also have been isolated from scab lesions on potato tubers produced in the major potato growing area in Korea. The characteristics of these organisms clearly differ from those of known scab pathogens.

The purpose of this work was to characterize major common scab pathogens in Korea based on morphological and physiological characters, analysis of 16S rRNA genes, production of thaxtomin A, and presence of necl and ORFtnp gene homologs.

\section{MATERIALS AND METHODS}

Bacterial strains and growth conditions. A total of 56 Streptomyces strains were isolated from potato scab lesions on field-grown potato tubers from different geographic locations using the method previously described $(8,19,27)$. Strains were grouped into six distinct clusters based on morphological characteristics $(17,18)$. Six representative strains were selected for use in this study (Table 1). The type strains of three pathogenic strains $(S$. scabies ATCC 49173, S. acidiscabies ATCC 49003, and S. turgidiscabies ATCC $700248)$ and one nonpathogenic strain $(S$. lividans ATCC 19844) were obtained from the American Type Culture Collection (University Boulevard, Manassas, VA).

Bacteria were routinely grown at $28^{\circ} \mathrm{C}$ on yeast-malt extract (YME) medium (28) containing (per liter) $10 \mathrm{ml}$ of the antibiotic stock solution (nystatin, $500 \mathrm{mg}$; polymyxin B sulfate, $50 \mathrm{mg}$; sodium penicillin-G, $10 \mathrm{mg}$; cycloheximide, $500 \mathrm{mg}$ per $100 \mathrm{ml})$. The strains were lyophilized and stored at $4^{\circ} \mathrm{C}$.

Pathogenicity tests. Strains were tested for pathogenicity based on the method of Loria and Kempter (25) with some modifications. Inoculum was prepared by adding $5 \mathrm{ml}$ of sterile water to sporulating cultures growing on YME agar plates. Two milliliters of the spore suspension was added to Erlenmeyer flasks $(500 \mathrm{ml})$ containing 50 $\mathrm{ml}$ of potato dextrose broth (PDB, Difco Laboratories, Detroit, MI); cultures were then incubated for 2 weeks at $28^{\circ} \mathrm{C}$. Sterile distilled water $(250 \mathrm{ml})$ was added to each flask. Potato (Solanum tuberosum L.) tubers of the scab-susceptible cultivar Daejima produced from greenhouse-grown plants and free of scab lesions were surface-sterilized in $0.6 \% \mathrm{NaOCl}$ for $10 \mathrm{~min}$, rinsed in distilled water, and planted in pots (19 $\mathrm{cm}$ diameter) containing sterilized sand. Seed pieces were thoroughly drenched with $40 \mathrm{ml}$ of the inoculum. Plants were fertilized weekly with a soluble fertilizer. Greenhouse temperatures were about 24 to $29^{\circ} \mathrm{C}$. Three seed pieces were placed in each pot, which was considered to be an experimental unit. Plants produced from seed pieces were harvested about 50 days after inoculation. All tubers in each pot were evaluated for symptoms of potato scab. Pathogenicity tests for all strains were repeated twice.

Pathogenicity was also tested on tuber slices (23). Cultures of test strains were grown on oatmeal agar plate (24) for 5 to 7 days at $28^{\circ} \mathrm{C}$, and agar plugs from the sporulating colonies were inverted onto disks of excised tuber tissue. Disks were 
incubated in a moist chamber at $28^{\circ} \mathrm{C}$ in the dark and evaluated for the presence of necrosis after 5 days. All tuber slice assays were repeated three to five times.

Physiological and morphological characterization. Spore color and colony color on YME media after 14 days of incubation at $28^{\circ} \mathrm{C}$ were examined and compared with those described in "Methuen Handbook of Colour," 1983, reprinted by Methuen London Ltd. $(17,18,29)$. Chain morphology was observed microscopically, and ability to produce melanin on tyrosine agar and peptone agar media was determined after 4,8 , and 12 days of incubation at $28^{\circ} \mathrm{C}$ (29). Sugar utilization by the strains as recommended by the International Streptomyces Project (ISP) was tested on basal medium (29). The lower $\mathrm{pH}$ limit that allowed growth was determined on YME adjusted to $\mathrm{pH} 3.0$ to 7.0 at 0.5 -unit intervals $(17,18)$. The toxicities of inhibitory compounds were determined on modified Bennett agar (17).

Polymerase chain reaction $(\mathrm{PCR})$ amplification. The PCR primers for $16 \mathrm{~S}$ rRNA gene were chosen by analyzing the previously published 16S rRNA sequences of S. scabies, S. acidiscabies, and S. turgidiscabies (31). Targeted DNA regions were amplified by using the following primer sets: 5'-TCACGGAGAGTTTGATCC-3' corresponding to positions 3 to 21 of $S$. griseus subsp. griseus 16S rRNA gene, and 5'-AGAAAGGAGGTGATCCAGCC-3' corresponding to positions 1511 to 1530 of $S$. griseus subsp. griseus 16S rRNA gene. Amplification was carried out with 5 pmol of each primer and Taq polymerase (2.5 U; Promega, Madison, WI) under the following conditions: denaturing at $95^{\circ} \mathrm{C}$ for $1 \mathrm{~min}$, annealing at $55^{\circ} \mathrm{C}$ for $1 \mathrm{~min}$, and extension at $72^{\circ} \mathrm{C}$ for $2 \mathrm{~min}$ for 30 cycles. The amplified fragments were then sequenced directly by cycling sequencing by using an ALFred autocycle sequencing kit with M13 forward and reverse primers. The sequences of the $16 \mathrm{~S}$ rRNA genes of Streptomyces were compared with other Streptomyces from the GenBank databases.

The necl and ORFtnp genes were amplified using the previously published PCR primers Nf-Nr and Tf-Tr, respectively (3).
The reaction mix contained 50 pmol of each primer set, $200 \mu \mathrm{M}$ dNTP, $20 \mathrm{mM}$ Tris- $\mathrm{HCl}$ (pH 8.0), $100 \mathrm{mM} \mathrm{KCl}, 0.1 \mathrm{mM}$ EDTA, $1 \mathrm{mM}$ dithiothreitol (DTT), 50\% glycerol, $0.5 \%$ Tween 20 and $0.5 \%$ Nonidet P40, 2.5 units of Taq DNA polymerase (Promega), and $50 \mathrm{ng}$ of total DNA under the following conditions: DNA denaturing at $95^{\circ} \mathrm{C}$ for $1 \mathrm{~min}$, annealing at $60^{\circ} \mathrm{C}$ for 1 min, and extension at $72^{\circ} \mathrm{C}$ for $2 \mathrm{~min}$ for 30 cycles. The amplified DNA was then run on $1 \%$ agarose gels and repeated twice.

Phytotoxin assay. Phytotoxins were extracted from OMB inoculated with each Streptomyces strain and potato slices inoculated with spores as described by Babcock et al. (1) and Toth et al. (33). Briefly, oatmeal broth $(100 \mathrm{ml})$ was inoculated with Streptomyces strains and incubated at $28^{\circ} \mathrm{C}$ on a rotary shaker $(150$ to $180 \mathrm{rpm})$ for 5 to 7 days. The cells were removed by centrifugation, and the supernatant samples were extracted three times with equal volumes of chloroform. The chloroform extracts were dried under vacuum using a rotary evaporator and then resuspended in acetone for detection of thaxtomin A by

Table 1. Streptomyces strains used in this study, their accession numbers of $16 \mathrm{~S}$ rRNA genes, pathogenicity on whole plant and tuber slices, thaxtomin A production by TLC and HPLC analysis, and hybridization to necl and ORFtnp genes

\begin{tabular}{|c|c|c|c|c|c|c|c|c|}
\hline \multirow[b]{2}{*}{ Strains $^{\mathrm{a}}$} & \multirow{2}{*}{$\begin{array}{l}\text { Accession nos. of } \\
\text { 16S rRNA genes }\end{array}$} & \multicolumn{2}{|c|}{ Pathogenicity $^{\mathbf{b}}$} & \multirow[b]{2}{*}{ TLC $^{c}$} & \multicolumn{2}{|c|}{ HPLC $^{d}$} & \multicolumn{2}{|c|}{ Hybridization $^{\mathrm{e}}$} \\
\hline & & Pot & TB & & $\mathbf{O A}$ & TB & nec1 & ORFtnp \\
\hline \multicolumn{9}{|l|}{ S. scabies } \\
\hline ATCC $49173^{\mathrm{T}}$ & D63862 & + & + & + & + & + & + & + \\
\hline S33 & AF361781 & + & + & + & + & + & + & + \\
\hline ATCC 33282 & D63863 & NA & NA & NA & NA & NA & NA & NA \\
\hline SNS-26 & D63864 & NA & NA & NA & NA & NA & NA & NA \\
\hline \multicolumn{9}{|l|}{ S. turgidiscabies } \\
\hline ATCC $700248^{\mathrm{T}}$ & D63866 & + & + & + & + & + & + & + \\
\hline S27 & AF361782 & + & + & + & + & + & + & + \\
\hline \multicolumn{9}{|l|}{ S. acidiscabies } \\
\hline ATCC $49003^{\mathrm{T}}$ & D63865 & + & + & + & + & + & + & + \\
\hline S71 & AF361783 & + & + & + & + & + & - & - \\
\hline \multicolumn{9}{|l|}{ Streptomyces spp. } \\
\hline S63 & AF361784 & + & + & + & - & - & - & - \\
\hline S77 & AF361785 & + & + & + & - & - & - & - \\
\hline S78 & AF361786 & + & + & + & + & + & - & - \\
\hline \multicolumn{9}{|l|}{ S. lividans } \\
\hline TK21 & Y00484 & - & - & - & - & - & - & - \\
\hline \multicolumn{9}{|l|}{ S. bottropensis } \\
\hline ATCC $25435^{\mathrm{T}}$ & D63868 & NA & NA & NA & NA & NA & NA & NA \\
\hline \multicolumn{9}{|l|}{ S. neyagawaensis } \\
\hline ATCC $27449^{\mathrm{T}}$ & D63869 & NA & NA & NA & NA & NA & NA & NA \\
\hline \multicolumn{9}{|l|}{ S. diastatochromo-genes } \\
\hline ATCC $12309^{\mathrm{T}}$ & D63867 & NA & NA & NA & NA & NA & NA & NA \\
\hline \multicolumn{9}{|l|}{ S. setonii } \\
\hline ATCC $25497^{\mathrm{T}}$ & D63872 & NA & NA & NA & NA & NA & NA & NA \\
\hline \multicolumn{9}{|l|}{ S. griseus subsp. griseus } \\
\hline KCTC 9080 & M76388 & NA & NA & NA & NA & NA & NA & NA \\
\hline \multicolumn{9}{|l|}{ S. sampsonii } \\
\hline ATCC $25495^{\mathrm{T}}$ & D63871 & NA & NA & NA & NA & NA & NA & NA \\
\hline \multicolumn{9}{|l|}{ S. eurythermus } \\
\hline ATCC $14975^{\mathrm{T}}$ & D63870 & NA & NA & NA & NA & NA & NA & NA \\
\hline \multicolumn{9}{|l|}{ S. tendae } \\
\hline ATCC $19812^{\mathrm{T}}$ & D63873 & NA & NA & NA & NA & NA & NA & NA \\
\hline \multicolumn{9}{|l|}{ S. coelicolor } \\
\hline $\mathrm{A} 3(2)$ & Y00411 & NA & NA & NA & NA & NA & NA & NA \\
\hline
\end{tabular}

a $\mathrm{T}$, type strain of the species; NA, not known or applicable.

${ }^{\mathrm{b}}$ Pot, pot test; TB, tuber slices; +, pathogenicity on pot test and tuber slice assays; -, nonpathogenicity on both tests.

${ }^{c}$ TLC, thin layer chromatography; +, comigrated spot similar to authentic thaxtomin A; -, no comigrated spot similar to authentic thaxtomin A.

${ }^{\mathrm{d}}$ HPLC, high-pressure liquid chromatography; OA, oatmeal broth culture; TB, tuber slices; +, detection of thaxtomin A; -, no detection of thaxtomin A.

e + , hybridization; -, no hybridization. 
thin layer chromatography (TLC) and highpressure liquid chromatography (HPLC).

Thaxtomins were also extracted from potato tuber slices inoculated with spores of each strain as described by Lawrence et al. (21). The inoculated potato tuber slices were soaked in methanol for $24 \mathrm{~h}$ and then homogenized for $1 \mathrm{~h}$ using an ultrasonic cleaner (Branson Ultrasonics Co., Danbury, CT). Cell debris and medium were removed by filtration, and the filtrate was extracted twice with equal volumes of chloroform. The chloroform extracts were dried using a rotary evaporator and dissolved in acetone for detection of thaxtomin A by HPLC.

Thaxtomins were observed on $0.25 \mathrm{~mm}$ Merk silica-gel $60 \mathrm{~F}_{254}$ precoated TLC in chloroform:methanol (9:1). The bands comigrating with authentic thaxtomin A standard were recorded. Thaxtomin A was identified by HPLC using a Shimadzu 10A system with a symmetry C18 column (Waters, $3.9 \times 150 \mathrm{~mm})$. Thaxtomin A was eluted with $25 \%$ acetonitrile over $20 \mathrm{~min}$ and monitored at $380 \mathrm{~nm}$.

Southern blot analysis. Total genomic DNA was digested with BamHI, separated by agarose gel electrophoresis, transferred to Hybond- $\mathrm{N}^{+}$nylon membranes by the manufacturer's capillary blotting method (Amersham Pharmacia Biotech, Little Chalfont Buckinghamshire, HP7 9NA,
UK), baked at $80^{\circ} \mathrm{C}$ for $2 \mathrm{~h}$, and hybridized to random primed DNA labeling with digoxigenin-dUTP labeled DNA probes made with the DIG DNA labeling and detection kit (Boehringer Mannheim, Detroit, MI). The fragments of necl $(0.72 \mathrm{~kb})$ and ORFtnp $(0.55 \mathrm{~kb})$ were amplified with primer sets according to Bukhalid et al. (3) and used as probes. Prehybridization and hybridization were done at $65^{\circ} \mathrm{C}$ for $3 \mathrm{~h}$ and overnight, respectively, in the following buffer: $5 \times$ SSC $(1 \times$ SSC is $0.15 \mathrm{M}$ $\mathrm{NaCl}$ plus $0.015 \mathrm{M}$ sodium citrate), $1 \%$ blocking reagent, $0.1 \% \mathrm{~N}$-lauroylsarcosine, and $0.02 \%$ sodium dodecyl sulfate (SDS). The most stringent wash was $2 \times$ SSC and $0.1 \%$ SDS at room temperature for $2 \times 5$ min and $0.1 \times \mathrm{SSC}$ and $0.1 \%$ SDS at $65^{\circ} \mathrm{C}$ for $2 \times 15 \mathrm{~min}$. DIG-labeled probes were then detected following the manufacturer's suggested methods (Boehringer Mannheim).

\section{RESULTS}

Pathogenicity. All six Korean strains induced scab lesions on tubers (Table 1, Fig. 1). Tuber lesions produced following inoculation with each isolate were similar and identical to those from scab lesions on field-grown tubers. In addition, pathogens reisolated from inoculated progeny tubers had spore color and morphology identical to those of the original pathogens. In tuber slice assays, all six strains induced necrosis on tuber slices (Fig. 1).

Phenotypic characterization. Strains were compared for substrate mycelium and spore color in mass, spore chain morphology, melanin production, sugar utilization, and resistance to inhibitory compounds (Table 2). Strain S33 was identical to the type strain of $S$. scabies, except that it failed to grow in the presence of 5 to $6 \%$ $\mathrm{NaCl}$ and was resistant to $10 \mathrm{IU} / \mathrm{ml}$ penicillin. Strain S27 was identical to the type strain of $S$. turgidiscabies except that it failed to produce melanin on peptone agar and was resistant to $10 \mathrm{IU} / \mathrm{ml}$ penicillin and $25 \mu \mathrm{g} / \mathrm{ml}$ oleandomycin. Strain S71 had characteristics similar to those of $S$. acidiscabies, except that its growth was inhibited below $\mathrm{pH} 4.5$ and it produced melanin on tyrosine agar and varied in its reaction to several antibiotics and other inhibitory compounds. Strain S63 produced yellow-white spores in a rectiflexuous chain, produced melanin on tyrosine or peptone agar, and utilized all the International Streptomyces Project (ISP) sugars. Growth of this strain was inhibited below $\mathrm{pH} 4.5$ and in the presence of 5,6 , or $7 \%$ $\mathrm{NaCl}$, thallium acetate $(100 \mu \mathrm{g} / \mathrm{ml})$, phenol $(0.1 \% \mathrm{vol} / \mathrm{vol})$, oleandomycin $(25,100$ $\mu \mathrm{g} / \mathrm{ml})$, and streptomycin $(20 \mu \mathrm{g} / \mathrm{ml})$. Strain S77 had pale orange spores in a rectiflexuous chain, produced melanin on

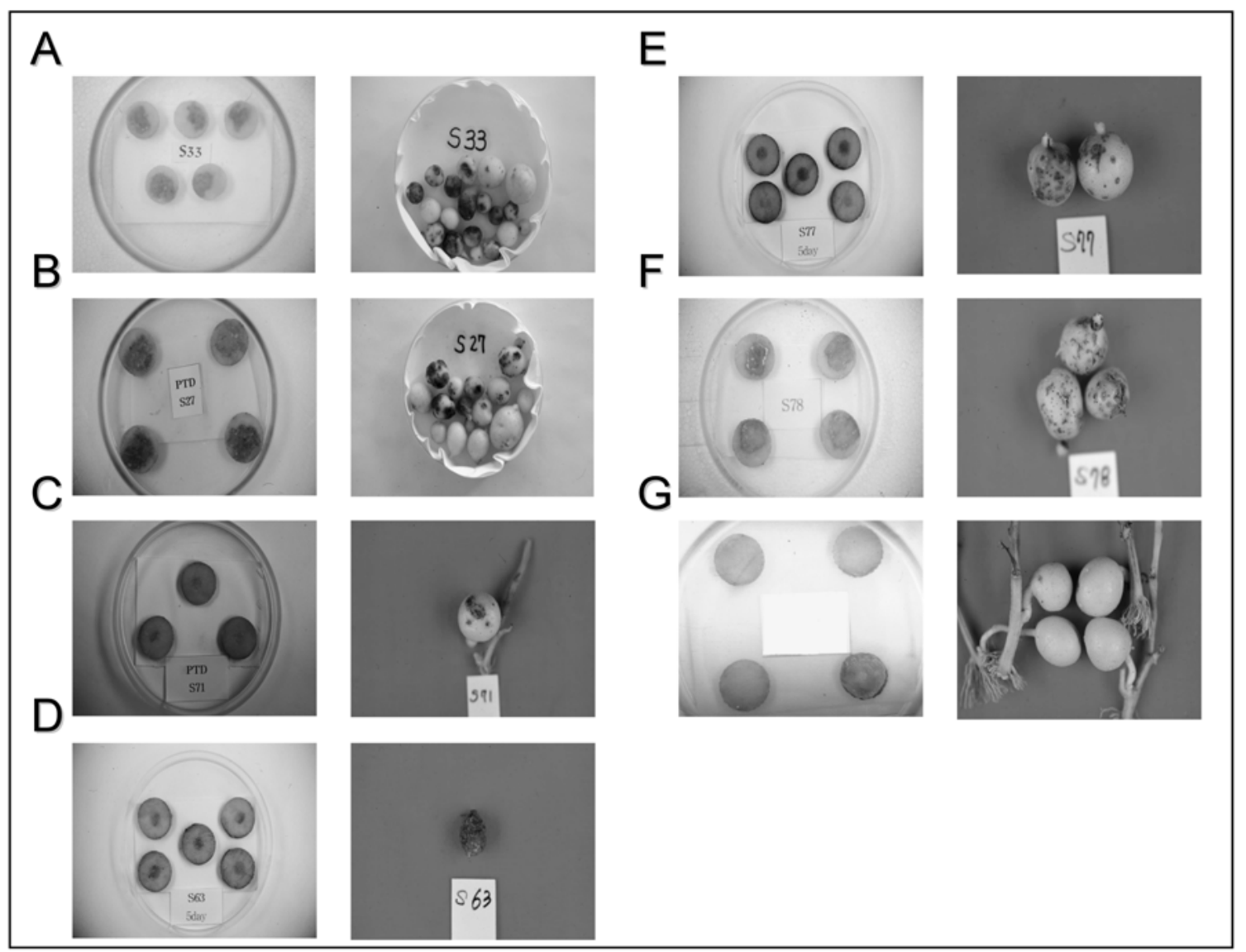

Fig. 1. Necrotic halos produced around agar plugs from 5-day-old oatmeal agar cultures of Streptomyces species (left) and lesions produced on potato tubers (right). A, S33, B, S27, C, S71, D, S63, E, S77, F, S78, and G, S. lividans ATCC 19844. 
tyrosine agar, and utilized all the ISP sugars. Growth was inhibited below $\mathrm{pH} 3.5$ and in the presence of thallium acetate $(10$, $100 \mu \mathrm{g} / \mathrm{ml})$ and streptomycin $(20 \mu \mathrm{g} / \mathrm{ml})$. Strain S78 had thin and compact spores in a rectiflexuous chain, did not produce melanin on tyrosine or peptone agar, and utilized all ISP sugars. The growth was inhibited below $\mathrm{pH} 3.5$ and in the presence of 5,6 , or $7 \% \mathrm{NaCl}$, thallium acetate $(10$, $100 \mu \mathrm{g} / \mathrm{ml})$, crystal violet $(0.5 \mu \mathrm{g} / \mathrm{ml})$, phenol $(0.1 \%)$, oleandomycin $(25,100 \mu \mathrm{g} / \mathrm{ml})$, and streptomycin $(20 \mu \mathrm{g} / \mathrm{ml})$. The morphological and physiological characteristics of the three strains (S63, S77, and S78) differ from those of described scab pathogens, such as $S$. scabies, $S$. turgidiscabies, and $S$. acidiscabies (Table 2).

Analysis of 16S rRNA genes. The complete sequences of the 16S rRNA genes of six strains causing potato scab disease were determined (Table 1, Fig. 2). Their sequences were compared with those in GenBank. Strain S33 was most similar to $S$. scabies strains (ATCC 49173, ATCC 33282, SNS-26) with sequence identities of more than $99.8 \%$. Phylogenetic analysis confirmed clustering of S33 with S. scabies strains in $100 \%$ of bootstrap replicates (Fig. 2). Strain S27 was most similar to $S$. turgidiscabies ATCC 700248 with sequence identities of $99.5 \%$, and clustering was supported by $100 \%$ of bootstrap repli- cates (Fig. 2). Strain S71 was identified as most similar to $S$. acidiscabies ATCC 49003 with sequence identities of $99.9 \%$, and these clusters were also supported by $100 \%$ of bootstrap replicates. In contrast, strain S63 had less than 96.0, 97.2, and $97.3 \%$, strain S77 had less than 95.2, 95.5, and $96.0 \%$, and strain S78 had less than 95.5, 96.1, and $96.3 \%$ similarities to three type strains of S. scabies, S. turgidiscabies, and $S$. acidiscabies, respectively.

Analysis of thaxtomin A production. Extracts of oatmeal broth culture of $S$. scabies (ATCC 49173 and S33), S. turgidiscabies (ATCC 700248 and S27), S. acidiscabies (ATCC 49003 and S71), and Korean strains (S63, S77, and S78) produced a yellow band that comigrated with authentic thaxtomin A by TLC analysis (Table 1). HPLC analysis of chloroform extracts from oatmeal broth and potato slices inoculated with spores showed a peak of thaxtomin A from all strains except S63 and S77.

PCR analysis of nec1 and ORFtnp genes. The predicted $720-$ and 550-bp products for the coding sequences of necl and ORFtnp, respectively, were obtained from S. scabies ATCC 49173 and strain S33, S. turgidiscabies ATCC 700248 and strain S27, and $S$. acidiscabies ATCC 49003 using the originally described primer sets (3). No precise product was obtained with the two primers from the pathogenic strains S71, S63, S77, and S78 and a nonpathogenic strain $S$. lividans ATCC 19844 (Fig. 3).

Southern blot analysis of the nec1 and ORFtnp genes. The necl probe hybridized to a single fragment $(>9.4 \mathrm{~kb})$ of genomic DNA from S. scabies (ATCC 49173 and S33) and S. turgidiscabies (ATCC 700248 and S27) and to a single fragment $(<5.0$ $\mathrm{kb}$ ) of genomic DNA from $S$. acidiscabies (ATCC 49003), but failed to hybridize to DNA from Korean $S$. acidiscabies strain S71, strains S63, S77, and S78, and nonpathogenic S. lividans ATCC 19844 (Fig. 4).

Similarly, the ORFtnp probe hybridized to one fragment of genomic DNA ( $>9.4$ $\mathrm{kb}$ ) from S. scabies (ATCC 49173 and S33), S. turgidiscabies (ATCC 700248 and S27), and S. acidiscabies (ATCC 49003), but failed to hybridize to genomic DNA from strains S71, S63, S77, and S78 and nonpathogenic $S$. lividans ATCC 19844 (Fig. 4). The additional homologous fragment $(<5.0 \mathrm{~kb}$ in size) from $S$. scabies ATCC 49173 hybridizing to ORFtnp previously reported by Bukhalid et al. (3) was not observed.

\section{DISCUSSION}

This paper presents the first extensive study of pathogenic bacterial strains inducing potato common scab disease in Korea,

Table 2. Phenotypic characteristics of Streptomyces causing potato scab in Korea

\begin{tabular}{|c|c|c|c|c|c|c|c|c|c|c|c|c|c|}
\hline Characteristics & S33 & S27 & S71 & S63 & S77 & S78 & $S . s^{\mathbf{a}}$ & S.t & S.a & S.c & S.e & S.st & S.r \\
\hline Spore color ${ }^{\mathrm{b}}$ & G & G & $\mathrm{W}$ & YW & $\mathrm{PO}$ & $\mathrm{W}$ & $\mathrm{G}$ & $\mathrm{G}$ & W & $\mathrm{W}$ & G & G & LG \\
\hline Chain morphology $\mathrm{y}^{\mathrm{c}}$ & $\mathrm{S}$ & $\mathrm{Rf}$ & $\mathrm{Rf}$ & $\mathrm{Rf}$ & $\mathrm{Rf}$ & $\mathrm{Rf}$ & $\mathrm{S}$ & $\mathrm{Rf}$ & $\mathrm{Rf}$ & $\mathrm{Rf}$ & $\mathrm{S}$ & $\mathrm{S}$ & $\mathrm{Rf}$ \\
\hline Colony color on $\mathrm{YME}^{\mathrm{d}}$ & TB & RY & LY & $\mathrm{OB}$ & GO & LY & $\mathrm{TB}$ & $\mathrm{Y}$ & $\mathrm{Br}$ & GB & ND & ND & ND \\
\hline Melanin on tyrosine agar & $+^{\mathrm{e}}$ & + & + & + & + & - & + & + & - & - & + & + & - \\
\hline $\begin{array}{l}\text { Melanin on peptone agar } \\
\text { Utilization }\end{array}$ & + & - & - & + & - & - & + & + & - & - & + & + & - \\
\hline L-Arabinose & + & + & + & + & + & + & + & ND & + & - & + & + & + \\
\hline D-Fructose & + & + & + & + & + & + & + & ND & + & - & + & + & + \\
\hline D-Glucose & + & + & + & + & + & + & + & ND & + & - & + & + & + \\
\hline D-Mannitol & + & + & + & + & + & + & + & ND & + & - & + & + & + \\
\hline Raffinose & + & + & - & + & + & + & + & + & - & + & + & + & + \\
\hline Rhamnose & + & + & + & + & + & + & + & ND & + & - & + & + & + \\
\hline Sucrose & + & + & + & + & + & + & + & ND & + & - & + & + & + \\
\hline D-Xylose & + & + & + & + & + & + & + & ND & + & - & + & + & + \\
\hline i-Inositol & + & + & + & + & + & + & + & ND & + & - & + & + & + \\
\hline $\begin{array}{l}\text { Minimum growth } \mathrm{pH} \\
\text { Growth with }\end{array}$ & 5.0 & 4.5 & 4.5 & 4.5 & 3.5 & 3.5 & 5.0 & 4.5 & 4.0 & 5.0 & ND & ND & ND \\
\hline $5 \% \mathrm{NaCl}$ & - & - & + & - & + & - & + & - & - & + & ND & - & - \\
\hline $6 \% \mathrm{NaCl}$ & - & - & + & - & + & - & + & - & - & $\mathrm{V}$ & ND & - & - \\
\hline $7 \% \mathrm{NaCl}$ & - & - & + & - & + & - & - & - & - & $\mathrm{V}$ & ND & - & - \\
\hline Thallium acetate & - & - & - & + & - & - & - & - & + & ND & ND & ND & ND \\
\hline Thallium acetate & - & - & - & - & - & - & - & - & - & ND & ND & ND & ND \\
\hline Crystal violet & - & - & + & + & + & - & - & - & + & $\mathrm{V}$ & - & - & - \\
\hline Phenol & - & - & - & - & + & - & - & - & + & + & ND & $\mathrm{ND}$ & ND \\
\hline Penicillin & + & + & + & + & + & + & - & - & + & + & + & + & + \\
\hline Oleandomycin & - & + & + & - & + & - & - & - & + & + & + & + & + \\
\hline Oleandomycin & - & - & + & - & + & - & - & - & - & $\mathrm{v}$ & ND & - & - \\
\hline Streptomycin & - & - & - & - & - & - & - & - & + & + & - & - & - \\
\hline
\end{tabular}

a Type strain of S. scabies (S.s), S. turgidiscabies (S.t), S. acidiscabies (S.a), S. caviscabies (S.c), S. europaeiscabiei (S.e), S. stelliscabiei (S.st), S. reticuliscabi (S.r) from references Bouchek-Mechiche et al. (2); Goyer et al. (9); Lambert and Loria (17,18); Miyajima et al. (26).

b G, gray; W, white; YW, yellowish white; PO, pale orange; LG, light gray.

c S, spiral; Rf, rectiflexuous.

d YME, yeast malt extract; TB, tan-brown; RY, red-yellow; LY, light yellow; OB, olive brown; GO, gray-orange; Y, yellow; Br, brown; GB, golden brown.

e +, positive reaction; -, negative reaction; v, between 20 and $90 \%$ of the strains were positive; ND, not determined.

f Thallium acetate, $10 \mu \mathrm{g} / \mathrm{ml}, 100 \mu \mathrm{g} / \mathrm{ml}$; crystal violet, $0.5 \mu \mathrm{g} / \mathrm{ml}$; phenol, $0.1 \%$; penicillin, $10 \mathrm{IU} / \mathrm{ml}$; oleandomycin, $25 \mu \mathrm{g} / \mathrm{ml}, 100 \mu \mathrm{g} / \mathrm{ml}$; streptomycin, $20 \mu \mathrm{g} / \mathrm{ml}$. 
and we believe that the six Korean representative strains (S33, S27, S71, S63, S77, and S78) characterized in this study are the major causal organisms of potato scab in Korea.

In these six Korean representative strains, three strains were identified as $S$. scabies (S33), S. turgidiscabies (S27), and $S$. acidiscabies (S71) according to their morphological and physiological properties and their $16 \mathrm{~S}$ rRNA sequence identity $(17,18,26,29)$. Spore color, spore chain morphology, and pigment production of the morphological and physiological properties

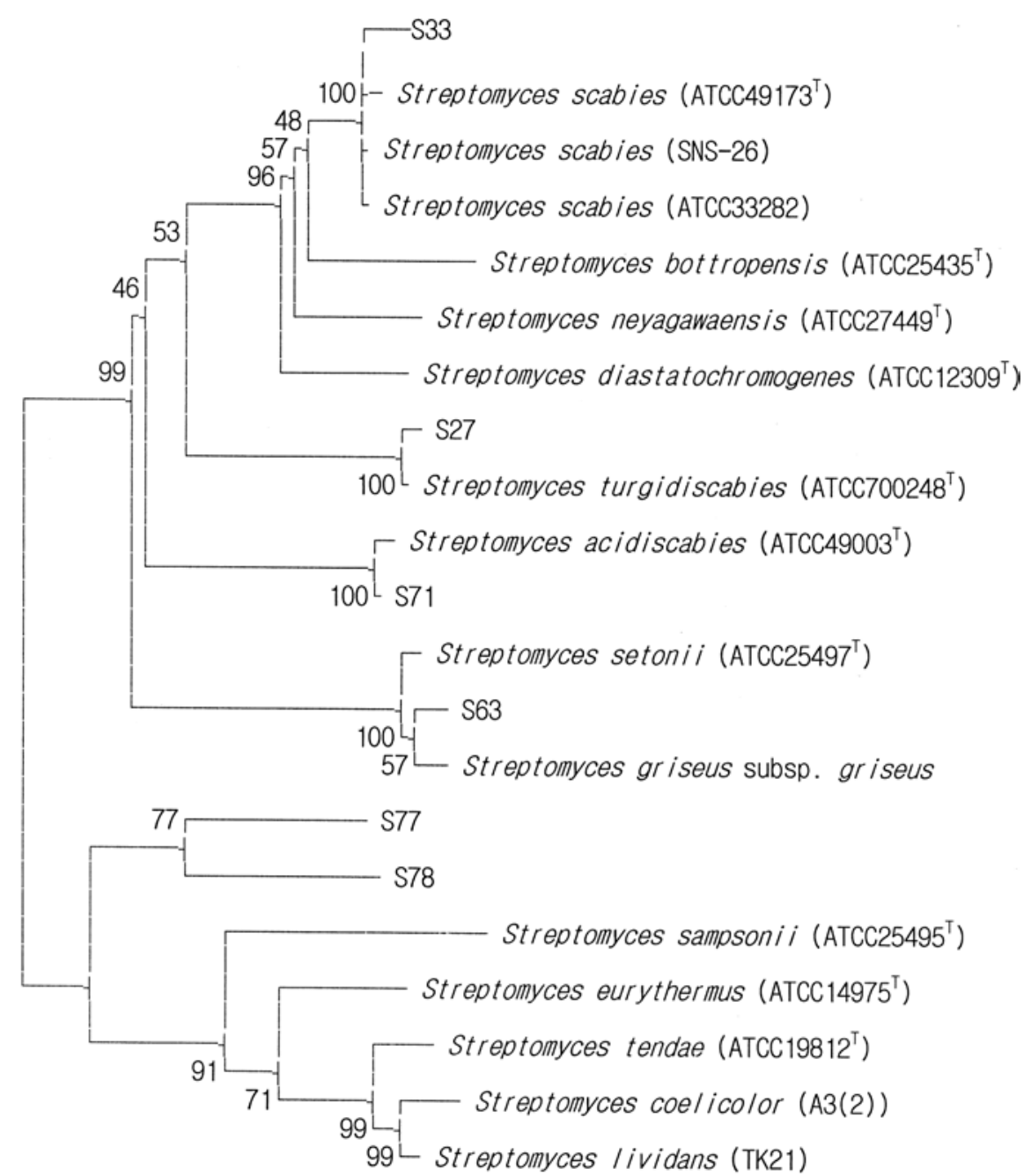

Fig. 2. Phylogenetic tree of Streptomyces spp. based on the $16 \mathrm{~S}$ rRNA gene sequences obtained by the Neighbor-Joining method. appeared to be the most reliable phenotypic criteria for their identification. Physiological characteristics such as minimum $\mathrm{pH}$ for growth, carbon utilization, and antibiotic resistance appear to be less consistent. The three remaining strains differed in phenotypic, morphological, and 16S rRNA sequence characteristics from known common scab pathogenic species $(17,18,26)$.

Strains S63 and S77 produced yellowwhite and pale orange spores, respectively. Strain S78 had white spores with rectiflexuous chain morphology, similar to $S$. acidiscabies. However, strain S78 had thin and compact colonies, distinct from that of typical S. acidiscabies ATCC 49003 (18). Growth of strain S63 was inhibited below $\mathrm{pH} 4.5$ and of strains S77 and S78 below $\mathrm{pH} 3.5$, suggesting that all three strains might have evolved to the commonly acidic soil conditions in Korea. Similar environmental adaptations were reported in several potato-growing areas in Canada, Europe, and Israel $(5,6,7,9,16,22)$. Therefore, we consider strains S63, S77, and S78 novel pathogenic species adapted to acidic soil condition in Korea.

Identity of the six pathogenic Korean Streptomyces strains based on 16S rRNA gene sequences was supported by the above grouping based on phenotypic properties. Our phylogenetic analysis was consistent with the previous reports of Takeuchi et al. (31), Kreuze et al. (16), and Bouchek-Mechiche et al. (2). In this study, strain S63 exhibited the highest levels of sequence similarity with $S$. setonii $(99.3 \%)$ and $S$. griseus subsp. griseus $(99.0 \%)$, which are placed in the subcluster 1B proposed by Williams et al. (34). But S. griseus and S. setonii were reported to be most closely related to the saprophytic Streptomyces CFBP 4543 by BouchekMechiche et al. (2). In DNA-DNA hybridization studies, however, strain S63 showed little homology with $S$. griseus and $S$. setonii at 10 and 7\%, respectively (unpublished data). Because DNA hybridization provides a more precise measure of the

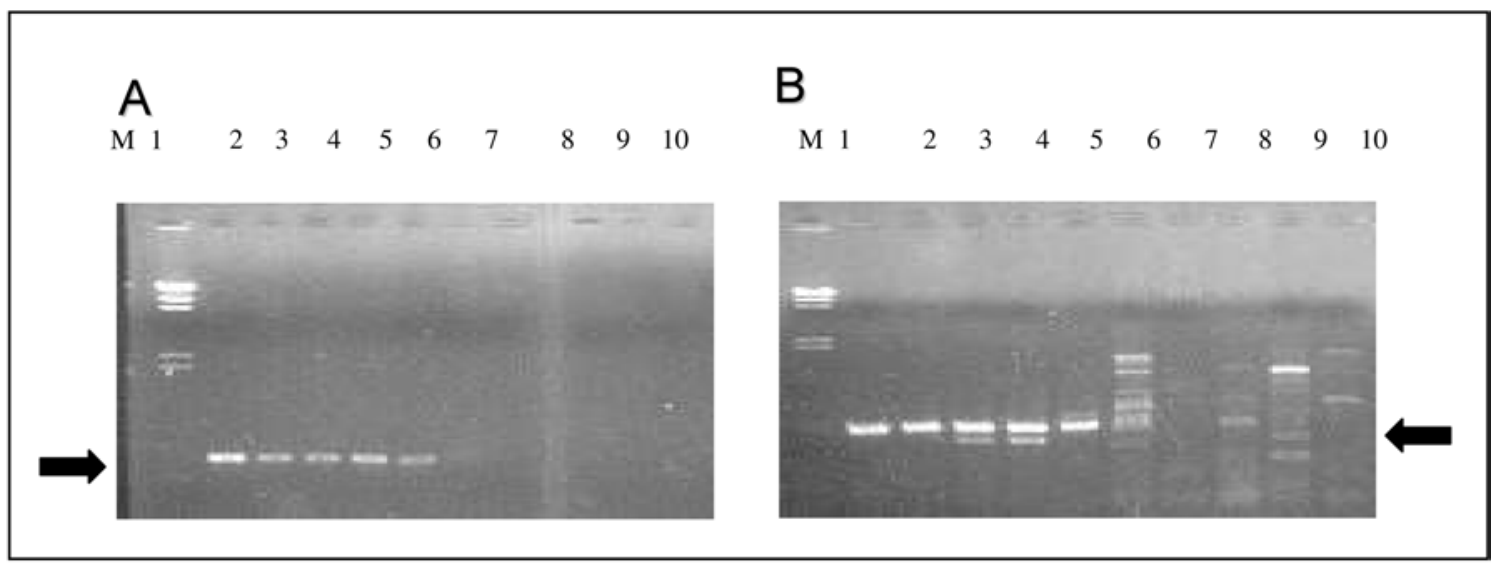

Fig. 3. Polymerase chain reaction amplification of the A, necl (720 bp); and $\mathbf{B}$, ORFtnp (550 bp). M: molecular marker (bacteriophage $\lambda$ DNA digested with HindIII), Lane 1: Streptomyces scabies ATCC 49173 ${ }^{\mathrm{T}}$, 2: S33, 3: S. turgidiscabies ATCC 700248 , 4: S27, 5: S. acidiscabies ATCC 49003 ${ }^{\mathrm{T}}$, 6: S71, 7: S63, 8: S77, 9: S78, 10: S. lividans ATCC 19844. Arrows are indicated for amplified necl (A, 720 bp) and ORFtnp (B, 550 bp) fragments, respectively. 
level of relatedness between highly related organisms $(2,30)$, we can conclude that strain S63 is phylogenetically distinct from other Streptomyces spp. The acid tolerant potato scab pathogens of Korea, strains S77 and S78, were distinct from any known Streptomyces spp.

To date, all strains of Streptomyces pathogenic to potato from diverse origins tested produce thaxtomin A $(1,9,21,23$, 24,33). In this study, chloroform extracts of oatmeal broth from all six Korean strains produced a yellow band, which comigrated with the thaxtomin A standard. Thaxtomin A was not detected from culture media of strains S63 and S77 by HPLC analysis. Each HPLC analysis was repeated twice; therefore, we believe failure to detect thaxtomin A production by these two strains was not due to any artifact. When chloroform extracts from tuber slices were analyzed by HPLC, again, thaxtomin A was not detected from strains S63 and S77, which clearly indicated that Korean strains S63 and S77 did not produce thaxtomin A either in the media or in potato tissues. Any pathogenic compounds produced by these two strains S63 and S77 will be characterized in a future study. Few reports on pathogenicity factors other than production of thaxtomin A, such as production of hydrolytic enzymes causing deep-pitted le-

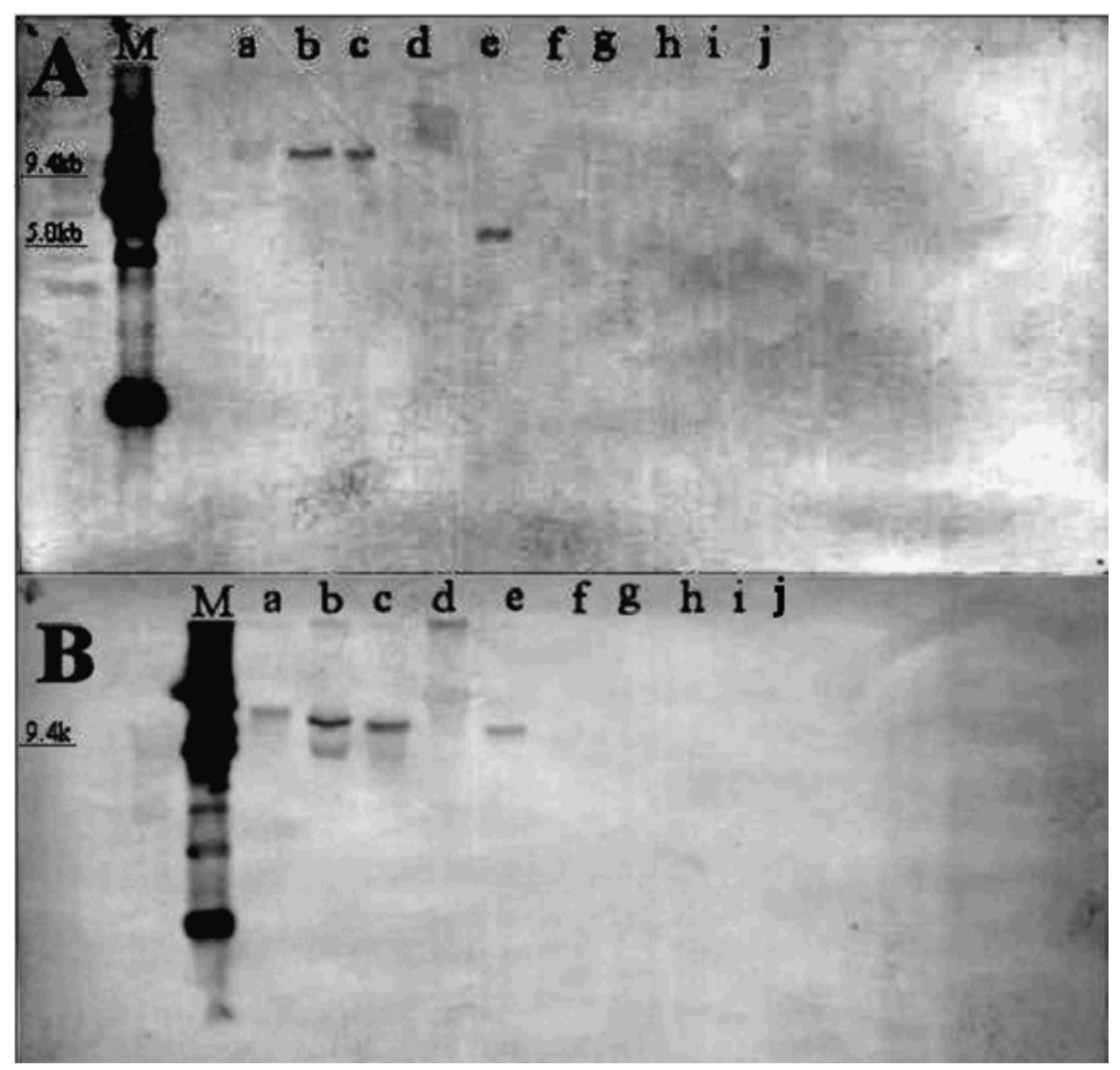

Fig. 4. Southern hybridization analysis of a BamHI digest of representative Streptomyces strains with A, necl (720 bp) and B, ORFtnp (550 bp) used as DNA probes. Lanes a and b are S. scabies ATCC $49173^{\mathrm{T}}$ and S33; c and d are S. turgidiscabies ATCC $700248^{\mathrm{T}}$ and S27; e and f are S. acidiscabies ATCC 49003 ${ }^{\mathrm{T}}$ and S71; g, S63; h, S77; i, S78; and j, S. lividans ATCC 19844. Sizes in base pairs are indicated for detected fragment of the necl and ORFtnp based on reference (4). of necl and ORFtnp gene homologs in these strains. However, the absence of these two genes in strains S71 and S78 is surprising. Both genes appear dispensable for pathogenicity and thaxtomin A synthesis, and their absence could reflect the loss of nonessential genes in the transfer of pathogenicity genes of Korean strains.

\section{ACKNOWLEDGMENTS}

We thank Calum Wilson, Tasmanian Institute of Agricultural Research, University of Tasmania, Australia, for critical reading of the manuscript. This work was supported by Agriculture and Forestry Special Research Funds from the Ministry of Agricultural and Forestry of Korea in 1997 to 2000 .

\section{LITERATURE CITED}

1. Babcock, M. J., Eckwall, E. C., and Schottel, J. L. 1993. Production and regulation of potato-scab inducing phytotoxins by Streptomyces scabies. J. Gen. Microbiol. 139:15791586.

2. Bouchek-Mechiche, K., Gardan, L., Normand, P., and Jouan, B. 2000. DNA relatedness among strains of Streptomyces pathogenic to potato in France: Description of three new species, S. europaeiscabiei sp. nov. and $S$. stelliscabiei $\mathrm{sp}$. nov. associated with common scab, and S. reticuliscabiei sp. nov. associated with netted scab. Int. J. Syst. Evol. Microbiol. 50:91-99.

3. Bukhalid, R. A., Chung, S. Y., and Loria, R. 1998. necl, a gene conferring a necrogenic phenotype, is conserved in plant-pathogenic Streptomyces spp. and linked to a transposase pseudogene. Mol. Plant-Microbe Interact. 11:960-967.

4. Bukhalid, R. A., Takeuchi, T., Labeda, D., and Loria, R. 2002. Horizontal transfer of the plant virulence gene, necl, and flanking sequences among genetically distinct Streptomyces strains in the diastatochromogenes cluster. Appl. Environ. Microbiol. 68:738744.

5. Doering-Saad, C., Kampfer, P., Manulis, S., Kritzman, G., Schneider, J., ZakrzewskaCzerwinska, J., Schrempf, J., and Barash, I. 1992. Diversity among Streptomyces strains causing potato scab. Appl. Environ. Microbiol. 58:3932-3940.

6. Faucher, E., Otrysko, B., Paradis, E., Hodge, N. C., Stall, R. E., and Beaulieu, C. 1993. Characterization of streptomycetes causing russet scab in Quebec. Plant Dis. 77:12171220.

7. Faucher, E., Paradis, E., Goyer, C., Hodge, N., Hogue, R., Stall, R. E., and Beaulieu, C. 1995. Characterization of streptomycetes causing deep-pitted scab of potato in Quebec, Canada. Int. J. Syst. Bacteriol. 45:222-225.

8. Faucher, E., Savard, T., and Beaulieu, C. 1992. Characterization of actinomycetes isolated from common scab lesions on potato tubers. Can. J. Plant Pathol. 14:197-202.

9. Goyer, C., Otrysko, B., and Beaulieu, C. 1996. Taxonomic studies on streptomycetes causing potato common scab: A review. Can. J. Plant Pathol. 18:107-201.

10. Healy, F. G., Bukhalid, R. A., and Loria, R. 1999. Characterization of an insertion sequence element associated with genetically diverse plant pathogenic Streptomyces spp. J. Bacteriol. 181:1562-1568.

11. Healy, F. G., Wach, M., Krasnoff, S. B., Gibson, D. M., and Loria, R. 2000. The txtAB genes of the plant pathogen Streptomyces acidiscabies encode a peptide synthetase required for phytotoxin thaxtomin A production and pathogenecity. Mol. Microbiol. 38:794804. 
12. Hooker, W. J. 1981. Common scab. Pages 3334 in: Compendium of Potato Diseases. American Phytopathological Society, St. Paul, $\mathrm{MN}$.

13. Kim, J. H., and Lee, W. H. 1996. Characterization of potato common scab pathogens from continuous cropping fields in Korea. Korean J. Plant Pathol. 12:109-115.

14. Kim, J. S., Park, D. H., Choi, Y. C., Lim, C. K., Hong, S. Y., Lee, S. D., Hahm, Y. I., and Cho, W. D. 1998. Potato scab caused by Streptomyces acidiscabies. Korean J. Plant Pathol. 14:689-692.

15. Kim, J. S., Park, D. H., Lim, C. K., Choi, Y. C., Hahm, Y. I., and Cho, W. D. 1998. Potato common scab by Streptomyces turgidiscabies. Korean J. Plant Pathol. 14:551-554.

16. Kreuze, J. F., Suomalainen, S., Paulin, L., and Valkonen, J. P. T. 1999. Phylogenetic analysis of $16 \mathrm{~S}$ rRNA genes and PCR analysis of the necl gene from Streptomyces spp. causing common scab, pitted scab, and netted scab in Finland. Phytopathology 89:462-469.

17. Lambert, D. H., and Loria, R. 1989. Streptomyces scabies sp. nov., nom. rev. Int. J. Syst. Bacteriol. 39:387-392.

18. Lambert, D. H., and Loria, R. 1989. Streptomyces acidiscabies sp. nov. Int. J. Syst. Bacteriol. 39:393-396.

19. Lawrence, C. H. 1956. A method of isolating Actinomycetes from scabby potato tissue and soil with minimal contamination. Can. J. Bot. 34:44-47.
20. Lawrence, C. H. 1964. Gale commne de la pomme de terre. Agric. Canada Publ. 953.

21. Lawrence, C. H., Clark, M. C., and King, R. R. 1990. Induction of common scab symptoms in aseptically cultured potato tubers by the vivotoxin, thaxtomin. Phytopathology 80:606-608.

22. Lindholm, P., Kortemaa, H., Kokkola, M., Haahtela, K., Salkinoja-Salonen, M., and Valkonen, J. P. T. 1997. Streptomyces spp. isolated from potato scab lesions under Nordic conditions in Finland. Plant Dis. 81:13171322.

23. Loria, R., Bukhalid, R. A., Creath, R. A., Leiner, R. H., Olivier, M., and Steffens, J. C. 1995. Differential production of thaxtomins by pathogenic Streptomyces species in vitro. Phytopathology 85:537-541.

24. Loria, R., Bukhalid, R. A., Fry, B. A., and King, R. R. 1997. Plant pathogenicity in the genus Streptomyces. Plant Dis. 81:836-846.

25. Loria, R., and Kempter, B. A. 1986. Relative resistance of potato tubers produced from stem cuttings and seed-piece-propagated plants to Streptomyces scabies. Plant Dis. 70:1146-1148.

26. Miyajima, K., Tanaka, F., Takeuchi, T., and Kuninaga, S. 1998. Streptomyces turgidiscabies sp. nov. Int. J. Syst. Bacteriol. 48:495502 .

27. O'Brien, J. G., Blanchette, R. A., and Sutherland, J. B. 1984. Assessment of Streptomyces spp. from elms for biological control of Dutch elm disease. Plant Dis. 68:104-106.

28. Paradis, E., Goyer, C., Hodge, N., Hogue, R. Stall, R., and Beaulieu, C. 1994. Fatty acid and protein profiles of Streptomyces scabies strains isolated in Eastern Canada. Int. J. Syst. Bacteriol. 44:561-564.

29. Shirling, E. B., and Gottlieb, D. 1966. Methods for characterization of Streptomyces species. Int. J. Syst. Bacteriol. 16:313-340.

30. Stackebrandt, E., and Goebel, B. M. 1994 Taxonomic note: A place for DNA-DNA reassociation and $16 \mathrm{~S}$ rRNA sequence analysis in the present species definition in bacteriology. Int. J. Syst. Bacteriol. 44:846-849.

31. Takeuchi, T., Sawada, H., Tanaka, F., and Matsuda, I. 1996. Phylogenetic analysis of Streptomyces spp. causing potato scab based on $16 \mathrm{~S}$ rRNA sequences. Int. J. Syst. Bacteriol. 46:476-479.

32. Tashiro, N., Miyashita, K., and Suzui, T. 1990. Taxonomic studies on the Streptomyces species, isolated as causal organisms of potato common scab. Ann. Phytopathol. Soc. Jpn. $56: 73-82$

33. Toth, L., Akino, S., Kobayashi, K., Doi, A., Tanaka, F., and Ogoshi, A. 1998. Production of thaxtomin A by Streptomyces turgidiscabies. Soil Microorganisms 51:29-34.

34. Williams, S. T., Goodfellow, M., Alderson, G. Wellington, E. M. H., Sneath, P. H. A., and Sackin, M. J. 1983. Numerical classification of Streptomyces and related genera. J. Gen. Microbiol. 129:1743-1813. 